\title{
Anna Bofill's Use of Mathematics in Her Architecture
}

\author{
María del Carmen Gómez-Collado ${ }^{1}$ (D) \\ Rafael Rivera Herráez ${ }^{2}$ - Macarena Trujillo Guillén ${ }^{1}$
}

\begin{abstract}
The work of Anna Bofill Levi, architect and composer, is an example of using mathematics to envision or conceive a project in both architecture and music. In this paper we focus on the architectural aspect and try to highlight the impact of mathematics on her work by analyzing several of her projects. The point of reference is the 1975 thesis on form generation written by Anna Bofill for the Universitat Politècnica de Barcelona. We conclude with excerpts from an interview with Anna Bofill herself.
\end{abstract}

Keywords Anna Bofill · Taller de Arquitectura · Design analysis · Modular aggregation · Isometries · Walden 7

\section{Introduction}

Anna Bofill Levi, architect and composer, uses mathematics as an inspiration for projects in both architecture and music. In this paper we focus on her architectural facet and try to show the influence of mathematics in her work by analyzing some of her projects. We focus mainly on her early work, and use as our reference her

María del Carmen Gómez-Collado

mcgomez@mat.upv.es

Rafael Rivera Herráez

rariher@urb.upv.es

Macarena Trujillo Guillén

matrugui@mat.upv.es

1 Instituto Universitario de Matemática Pura y Aplicada (IUMPA), Universitat Politècnica de València, Camino de Vera s/n, 46022 Valencia, Spain

2 Departamento de Urbanismo, Escuela Técnica Superior de Arquitectura, Universitat Politècnica de València, Camino de Vera s/n, 46022 Valencia, Spain 
doctoral thesis (Bofill Levi 1975), in which she explains how to use simple shapes such as cubes to generate more complex geometrical forms. As if in a game, mathematical rules and laws are used to achieve three-dimensional figures that provide infinite possibilities for constructing different structures, with isometries being mainly responsible for the diverse compositional alternatives. In her thesis, Bofill opens up new territory for modular aggregation and her proposals provide new ideas to expand the range of conformations in order to confer flexibility and adaptability on the structures she creates, fleeing from what she calls "the cold rigid urban landscape of blocks"1 (Bofill Levi 1975).

This present paper is divided in four parts: In the first we look at Anna Bofill's life, the settings in which she moved and the society in which she lived. In the second, we analyze the mathematical content of her thesis, which served as the basis of the design of the projects carried out by Ricardo Bofill's Taller de Arquitectura between 1964 and 1975. In the third we consider the module and its mathematical treatment. Finally, the fourth contains passages from an interview with Anna Bofill in which she gives her own reflections on her thesis and the projects related to it.

\section{Anna Bofill Levi, Architect and Composer}

From early childhood, Ricardo (Barcelona, 1939) and Anna (Barcelona, 1944) Bofill lived with their father's architecture and their mother's passion for art and music. Ricardo, who decided to study architecture following in his father's footsteps, entered the Barcelona School of Architecture but was soon after expelled for his political leanings and went off to Switzerland to continue his studies there. Anna, who was passionately in love with music from her earliest years, had planned to go to Italy after leaving school, but her elder brother died and since Ricardo was studying in Geneva, she stayed in Barcelona to be with her mother. It was then, in 1962, that she began to study architecture. In a later interview she once declared: "it seemed like the discipline that was most like music. Loads of different options went through my head...I was interested in so many different things and even today I am still interested in everything related to the world of science and research” (González Virós 2006).

\section{The Taller De Arquitectura}

Between 1962 and 1963 Ricardo Bofill, after returning to Barcelona, founded the Taller de Arquitectura. At the time a multidisciplinary "laboratory for architecture" was a new concept. It is with this stage of the Taller, in which Anna Bofill participated.

Together with Ricardo Bofill, the architects Manolo Núñez, Xavier Bagué and Peter Hodgkinson, were the original pillars of the Taller. Other members from other disciplines included as José Agustín Goytisolo (poet), Eduard Bonet (mathematician and husband of Anna Bofill), Serena Vergano (actress) and Salvador Clotas (politician and writer) (García 2013: 60). This multidisciplinary group, whose aim was to revitalize contemporary architecture, proposed new lines of action and

\footnotetext{
${ }^{1}$ All the Anna Bofill's quotations are made by authors.
} 
questioned the then current ways of thinking and projecting, and their ideas and methods revolutionized a whole generation. Anna Bofill joined the Taller de Arquitectura in 1964, when they were commissioned to carry out the Barrio de Reus project, which began by looking into how urban and architectural forms were generated. The aim of the Taller was to

design and construct houses that would be an alternative to the housing committees and the typical rationalist apartment blocks of those times, which were based on the town planning standards of the Athens Charter produced by the CIAM convention in 1933

(Bofill Levi 2010). The team of architects, mathematicians, writers, artists, sociologists and economists generated a dynamic atmosphere that favored investigation and experiments with forms in order to achieve their objectives. Even though Anna could have approached this investigation from other directions, she opted to use mathematics and its laws as her tools for creating forms, and the results can be seen in the projects carried out by the Taller between 1964 and 1975. In her thesis on "A Contribution to the Study of the Generation of Architectonic and Urban Forms" (1975) she had outlined the mathematical basis, which she called "Theory of Forms" for the geometrical treatment of modules that was to be used in most of the projects. There she also explained the work process and planning method involved in the theory and how it could be used to achieve the aims of the Taller. The theory promised to be a new approach to architecture and a new way of organizing spaces that would make possible new lifestyles and new social relations and structures.

The Taller's versatility in generating forms was approached mainly by the method of modular aggregation. Influenced by Rafael Leoz and Louis I. Kahn, among others, the projects they carried out between 1964 and 1975 were based on simple modules that became complex spatial compositions by means of the laws of aggregation. Together with Eduard Bonet and José Agustín Goytisolo, Anna's work consisted of establishing the mathematical models or algorithms that would explain the laws of aggregation for the generation of forms.

A number of modular-based buildings were carried out by the Taller between the first modular experience in 1963, with the El Sargazo Apartments (Castelldelfels, Barcelona), and that of Walden 7 (San Just Desvern, Barcelona) in 1975, including: The Barrio Gaudí (1964, Reus, Tarragona), the Castell de Sitges (1965, Sant Pere de Ribes, Barcelona), the Xanadú Building (1966, Calpe, Alicante) and the Muralla Roja (1968, Calpe, Alicante), La Ciudad en el Espacio (1970, Madrid) and the Petite Cathedrale (1971, Cergy-Pontoise, París). With each project, the modular aggregation process and its laws of composition became more refined, the modules more simple (Fig. 1) (García 2013: 83) and the proposals more systematized.

In Walden 7 (Fig. 2), which was perhaps the culmination of the Taller's achievements during this period, a cube was used as the basis of the structure, the apartments were composed of repetitions on this theme, and the different isometries of the module generate spaces between the apartments. The novelty of Walden 7 lay in the fact that the cubes could be placed in juxtaposition with each other in order to generate external concave or convex spaces. Not all the apartments were composed of the same number of cubes, nor were they on the same level, which gave the 
A
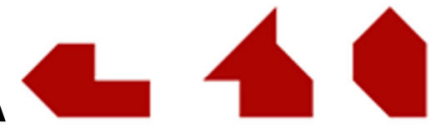

C

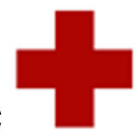

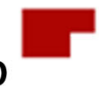
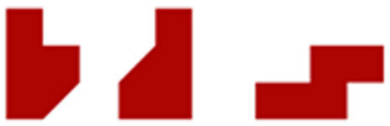

B

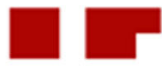

Fig. 1 The modules used in the different projects: a Barrio Gaudí; b Xanadú; c Muralla Roja; d Castell de Sitges; e Ciudad en el Espacio; f Walden 7; g Petite Cathedrale
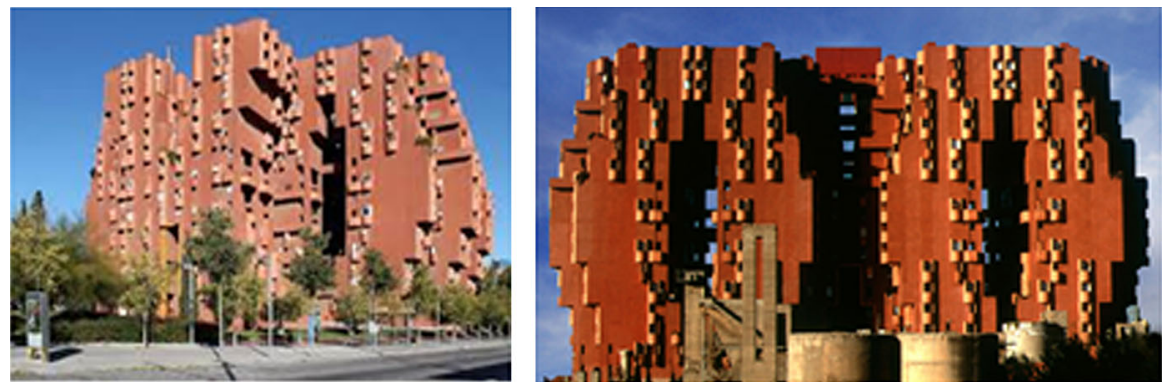

Fig. 2 Photos of Walden 7

building a certain labyrinthine appearance. Curiously enough, even though the conceptual rigidity of its geometry makes the structure seem flexible and haphazard. This project was one of the Taller's most emblematic projects and marked a turningpoint in Spanish architecture.

Walden 7 was completed in 1975, 10 years after Anna Bofill began research on the Theory of Forms, and marked the end of an era. It was in this year also that Anna defended her doctoral thesis at Universitat Politècnica de Barcelona.

\section{Her Own Workshop, Generic Urban Planning and Music}

Between 1981 and 1982 Anna Bofill left the Taller de Arquitectura and thus stopped working with her brother Ricardo. At this time she also became divorced from her husband. These two great changes marked the start of the second phase of her career. While she did not abandon the most classical facet of her profession, the construction of buildings, her interest was now focused on gender-inclusive urban planning (or the feminine vision of the city and its architecture). Today she is an undisputed leader of feminism in architecture and has carried out many projects incorporating the perspective of gender, for example, her "libro blanco" on women and the city (Bofill Levi et al. 1998), and her guide to urban planning, which includes gender criteria (Bofill Levi 2008).

Even though she had given up the idea of studying music in Italy, and studied architecture instead, she did not abandon music altogether. The creative process she used in her musical compositions was practically the same as that used in her 
architectural and urban compositions (Martín Nieva 2002: 63). In 1971, when she was immersed in the Walden 7 project, she composed her first piece of music, Esclat, in the first and fifth part of which she used the same geometric approach used for Walden 7, based on isometries and algorithms. Further, the relationship between tones and rhythmic groups follows the Theory of Probability and the Monte Carlo Method. In 2009 she explained the mathematical basis of her musical compositions in a paper read before the Second Schelling Conference on Art and the Humanities in Munich (Bofill Levi 2010).

\section{Anna Bofill Levy's Theory of Forms}

Anna Bofill assimilates architectural space to geometric space in order to be able to manipulate the surroundings systematically and rationally so as to find mathematical and geometric laws able to generate volumetric structures from basic elements, which she defines as minimum cells. As if it were a building game, at first, in an attempt to systematize the development process, she lays down the rules for grouping the pieces that will form the structure and then chooses the piece or pieces to be manipulated according to certain rules. Modules or units thus become bodies or developments of a certain size. We shall use the same method to try to give an insight into the Theory of Forms described in her thesis.

\section{Minimum Cells, Application of Isometries, Experimental Phase}

The generative geometric laws used to create volumes are those that regulate rigid motions or isometries, that is, movements carried out on an object that do not alter its form or its size but only its position in a space, so that its dimensions (perimeter, area and volume) do not change. This process could be suitably adapted to the building requirements of the time and the available prefabrication methods. The isometric transformations include translations, rotations, and symmetries.

The basic elements able to generate the urban fabric by means of isometries are based on different criteria: use, relation to surroundings, the supporting infrastructure network, possibilities for growth of the volumetric elements generated, etc. This latter condition necessarily requires the existence of a vertical direction and horizontal planes (by the law of gravity, the minimum displacement effort requires horizontality). Under these conditions, the best elements are evidently parallelepipeds.

After choosing the basic elements and the geometric laws, experiments are carried out with repeated applications of these laws to obtain a description of the more complex structures that can be systematically obtained. As a particular case of the parallelepiped, the cube is often resorted to in this experimental phase. With the aid of the Mathematica ${ }^{\circledR}$ software, following the mathematical expressions that define these movements, we replicated some of the movements described by Anna Bofill Levy in her 1975 thesis. We used blue to identify the original basic elements and yellow for the transformations. 
- Translation

In Fig. 3 various schemes are shown that include translations. Figure $3 \mathrm{a}-\mathrm{c}$ are those of Unit L, Cross Unit, and an extract from Unit $\mathrm{U}$ in her thesis.

- Rotation

Figure 4 shows the result obtained from Unit $U$ after applying a $90^{\circ}$ counterclockwise rotation to it around the $O Z$ axis on the $X Y$ plane.

- Helical motion

Figure 5 contains an example of the repeated application of helical movement around axis $O Z$ of a parallelepiped with a square base and height equal to half of the edge.

- Symmetry with respect to a plane

Figure 6 shows the Unit L shown in Fig. 3a and the symmetry with respect to the $Y Z$ plane.

\section{Units Formed from Cubes}

As we have seen above, applying isometries to minimum cells generates a series of configurations. In this phase there are many possibilities but only a few are chosen to make up units (or modules) such as those shown in Fig. 3. When a configuration is called a unit it means that it has the potential to become a module in the development of a more complex structure.

If isometrics are applied to minimum cells fixing a specific condition (e.g. that the basic and transformed elements share a common surface edge or vertex) units are obtained. Taking a cube as the basic element, we can obtain new units by applying different isometries, such as those shown in Fig. 7.

Not all the units have the same potential, as the architectural vision of the desired objective and the particular conditions of the project will determine the suitability of one arrangement over another.

\section{Forming Bodies}

Applying rigid motion to units, other more complex structures can be obtained, identified as "bodies" by Bofill in her thesis. The range of configurations is quite

A

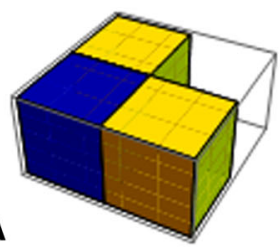

B

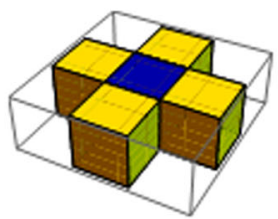

C

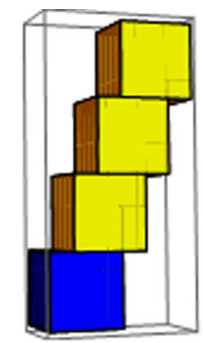

Fig. 3 Examples of translations applied to a cube: a Unit L. b Cross Unit. c Unit U 


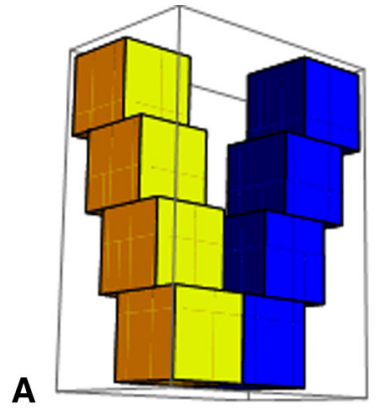

B

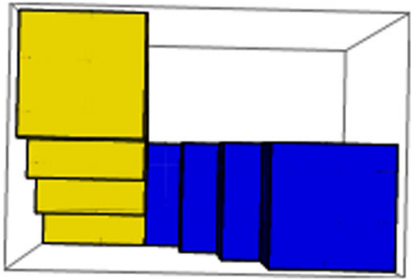

Fig. 4 Example of a rotation applied to Unit U. a Perspective; b plan

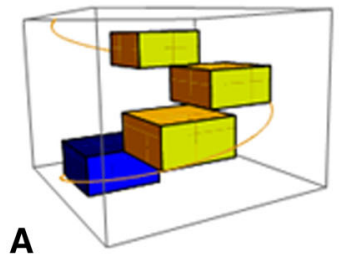

B

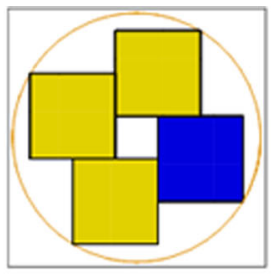

C

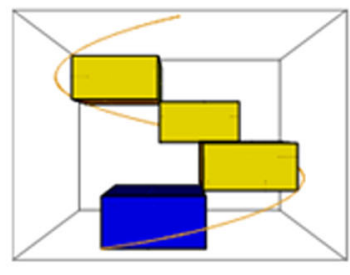

Fig. 5 An example of helical motion applied to a parallelepiped: a perspective, $\mathbf{b}$ plan and $\mathbf{c}$ elevation. The helix described by the motion is shown in orange

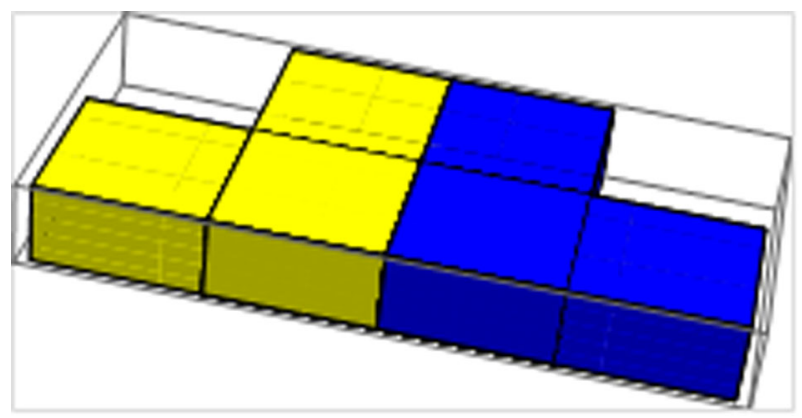

Fig. 6 Example of symmetry with respect to an axis applied to Unit L. The original is shown in blue and the transformed in yellow

large and it is important to emphasize the existence of relationships among the bodies and the use they will be put to. Some examples are as follows:

- Bodies formed from the Cross Unit

In Fig. 8 various examples can be seen of bodies formed from the Cross Unit. In Fig. 8a linear translation was applied four times of vector $(a, a, a), a$ being the cube edge. This inclined linear development is suitable for urban projects on sloping terrain. Applying together the translations of vectors $a(1,1,1), a(1,-1,1)$, $a(-1,-1,1), a(-1,1,1)$ the body shown in Fig. 8b. In Fig. 8c another example can be seen of a body for forming more complex structures known as nuclei (see 


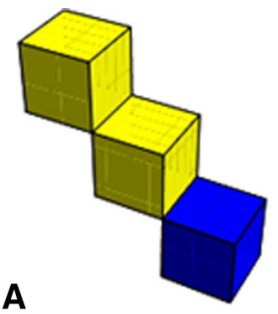

B

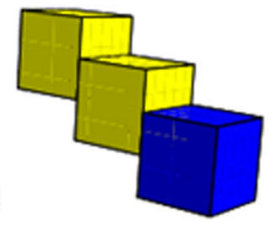

C

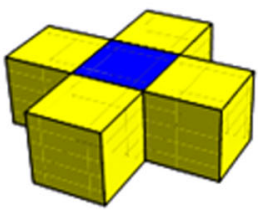

Fig. 7 Units with various cubes formed by translation of a cube: a translation according to vector $(a, 0$, $a), a$ being the value of the cube edge; $\mathbf{b}$ translation according to vector $(a, 0, a / 2), \mathbf{c}$ translation according to vectors $( \pm a, 0,0),(0, \pm a, 0)$ (Cross Unit)

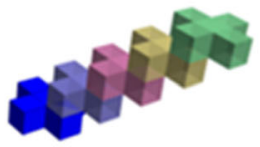

A

B

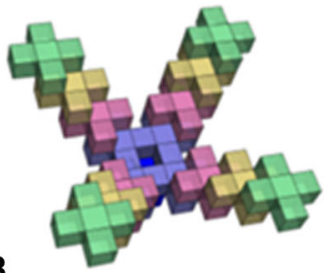

C

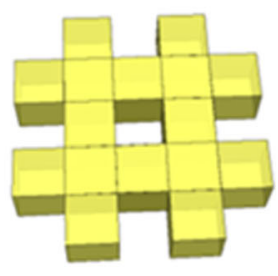

Fig. 8 Examples of bodies obtained from Cross Unit: a by means of translation of vector $(a, a, a)$, $a$ being the cube edge; $\mathbf{b}$ by translating vectors $a(1,1,1), a(1,-1,1), a(-1,-1,1), a(-1,1,1) ; \mathbf{c}$ body used to form Nuclei

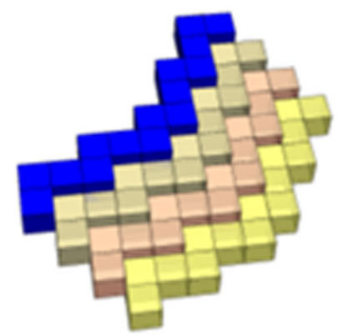

A

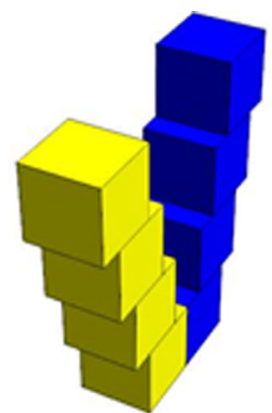

B

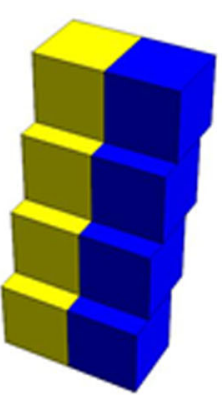

C

Fig. 9 Examples of bodies formed from different units: a Unit L. b, c Unit U

below). The central empty spaces generated by this body can be used as patios or small courtyards in more complex developments.

- Bodies formed from the Unit L

Figure 9a shows an example of a body formed from the Unit L. To form the pseudo-unit double $L$ we first consider the Unit $L$ and its horizontal translation according to vector $(-2,1,0)$, and then perform a repeated translation of vector $(1,1,-0.5)$ on the pseudo-unit. Nesting various of the bodies obtained, we now have low-density urban tissues that can be adapted to inclined sites or used as holiday flats. 
- Bodies formed from Unit U

Figure 9 shows examples of bodies formed from the Unit $U$ after performing symmetrical motions with respect to a vertical plane (Fig. 9b) and horizontal plane (Fig. 9c). The symmetry with glide is equivalent to adding a translation to the three previous symmetries.

\section{Formation of Nuclei, Linear Developments and Urban Fabrics}

Increasing the complexity of the structures, in this section we give some examples considered in Anna Bofill's thesis of how to form possible urban nuclei, their linear development, and urban fabrics.

If we think in terms of urban development and consider growth in relation to surface areas, we prefer the horizontal direction, so the useful rigid motions are reduced to translations on a horizontal plane and symmetries with respect to vertical planes.

Figure 10 shows the nucleus obtained from the body formed by two Cross Units by a series of symmetries (Fig. 10a). Combining this nucleus different horizontal developments are obtained (Fig. 10b). If vertical development is also considered we can obtain nuclei like that shown in Fig. 10c, obtained from a helical motion with a $90^{\circ}$ rotation in each step and vertical translation of the vector with the cube edge module. This, in turn, can connect with analogous nuclei following the linear development seen in Fig. 10b to obtain the urban network shown in Fig. 10d.

A

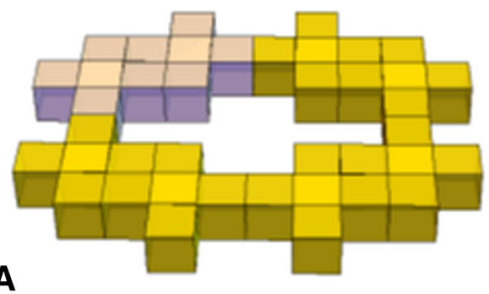

C

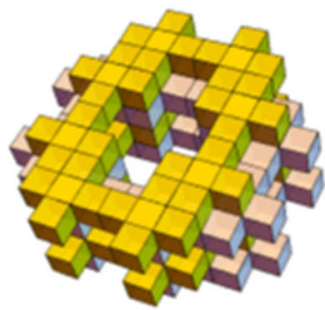

B
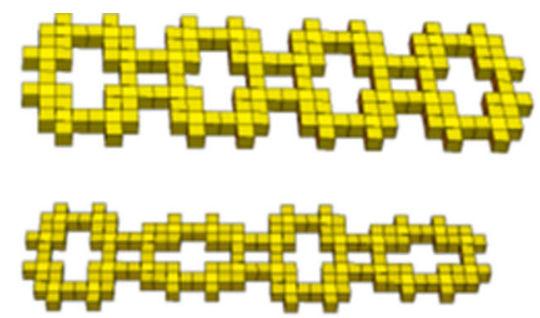

Fig. 10 a Nucleus obtained from a series of symmetries of the body formed by two Cross Units; b horizontal developments obtained from the nucleus in a; c vertical developments obtained from the nucleus in $\mathbf{a} ; \mathbf{d}$ urban mesh formed following the lineal developments of $\mathbf{b}$ and $\mathbf{c}$ 

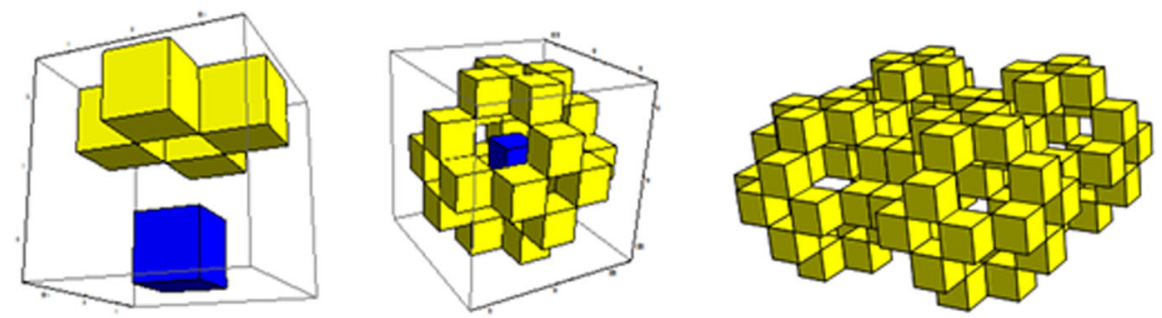

Fig. 11 Body (center) and nucleus (R) generated from translation motion shown in the figure on the left
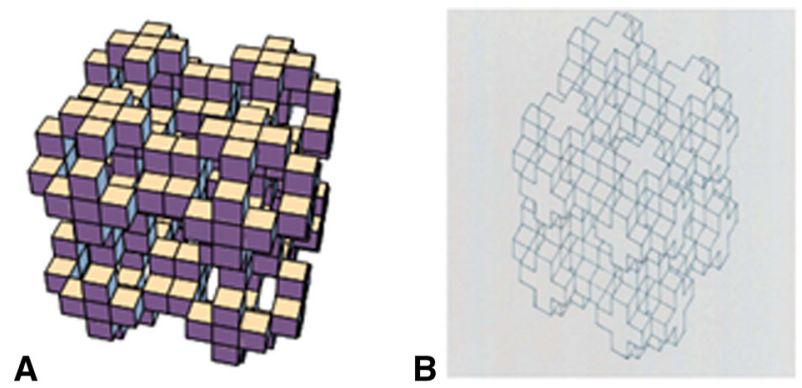

Fig. 12 Result of successive developments that could be obtained from the body in Fig. 10. a Graph made with Mathematica ${ }^{\circledR}$; b drawing from Bofill Levi's thesis (1975: 88)

Using the movement of the knight in chess, units, bodies and nuclei can be developed as shown in Fig. 11.

Figure 12 shows the result that would be obtained after successive development phases of the body shown in Fig. 11 applying symmetry with respect to the planes tangential to the surfaces.

From the stepped unit obtained from a cube according to vector $(a, 0, a / 2)$ (Bofill Levi 1975: 180ff.), linear developments are considered with the aim of configuring galleries that are semi-covered and covered, and of converting a covered to a semicovered gallery (Fig. 13). The motions that define these developments are the translation of the stepped unit (translation in a straight and oblique line) and the symmetry with respect to a vertical plane. Figure 13 again shows (L).

\section{Extrapolation of the Theory of Forms to the Taller Projects}

Here we shall concentrate on a study of Walden 7 as the typical example of the Taller de Arquitectura's working method during the period we are interested in. Walden 7 can be described as a type of vertical maze with seven interior patios interconnected vertically and horizontally. The structure is similar to a city district that has both a horizontal and vertical extension, with 16 floors (including the roof terrace), a surface area of $31.140 \mathrm{~m}^{2}, 446$ apartments, and 1000 residents.

From the mathematical standpoint it is an example of a nucleus formed of units and stepped bodies formed by four successive translations of a cube. Translations, 

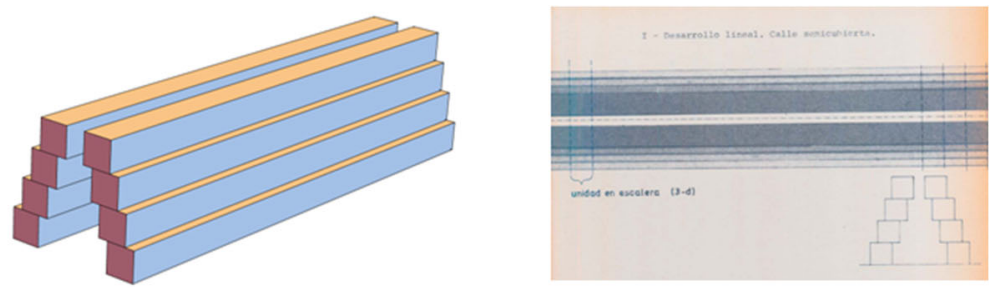

A
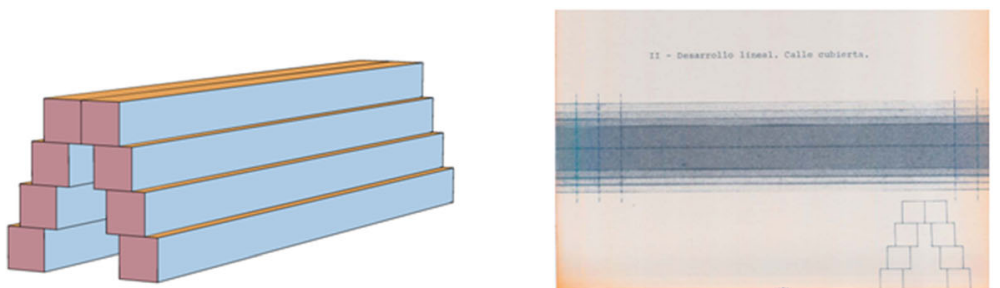

B
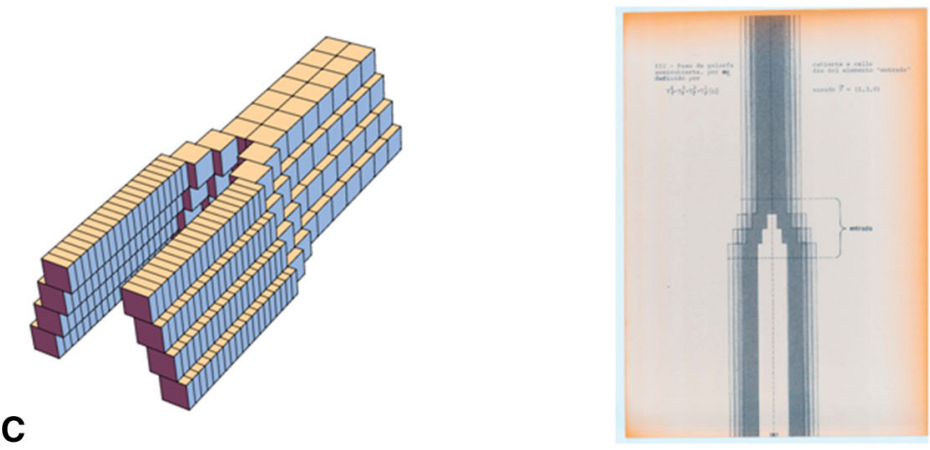

Fig. 13 Various linear developments obtained from a stepped unit, with the graphs made with Mathematica ${ }^{\circledR}$ on the left, and the drawings from (Bofill Levy 1975: 181-182) on the right: a development to configure a semi-covered gallery; b development to configure a covered gallery; c development to convert a covered to a semi-covered gallery

horizontal and vertical plane symmetry are applied to the nuclei to configure the modules of which the structure is composed.

Figure 14 shows the drawings of the aggregation system from (Bofill Levi 1975: 137-138), on which Walden 7 was based.

Below (Fig. 15) we show the drawings made with Mathematica ${ }^{\circledR}$ of the modular groups considered in the construction of Walden 7. 

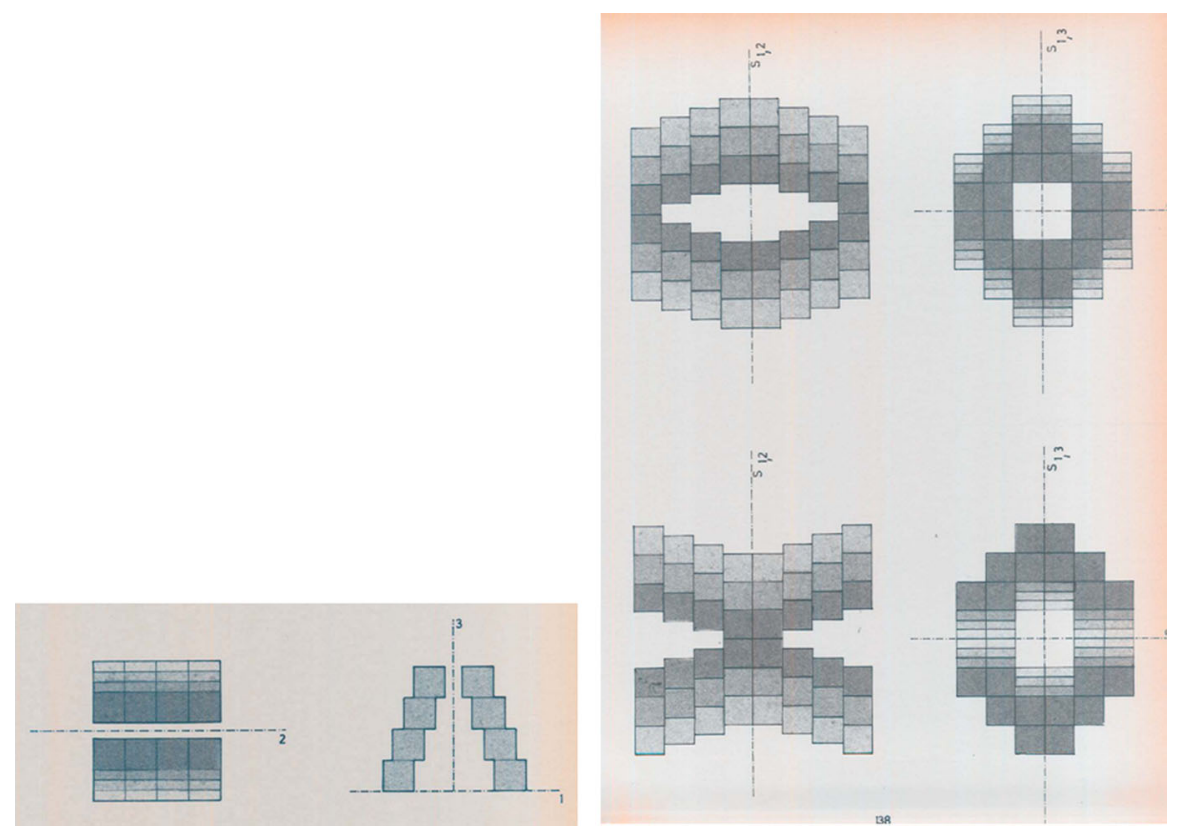

Fig. 14 Schemes from A. Bofill's thesis for Walden 7
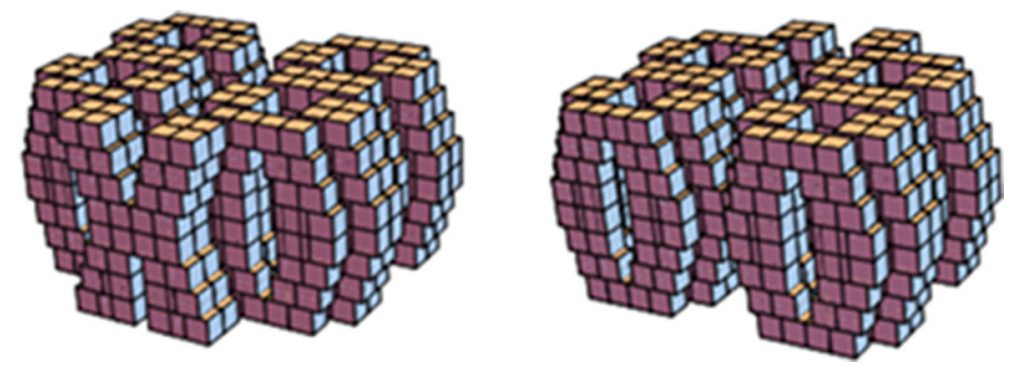

Fig. $15(L)$ Model of front and $(R)$ back of Walden 7 created with Mathematica ${ }^{\circledR}$

\section{The Binomial of Math and Architecture}

\section{The Reason for the Theory of Forms}

In order to understand the reasons that led Anna Bofill to create her Theory of Forms and the Taller to undertake the projects they carried out between 1963 and 1975 we have to go back even further in time.

The Modernist Movement in urban planning began after the founding of the CIAM, and especially after its fourth congress in 1933, which gave rise to the Athens Charter, taken as the model for the new conception of town planning. This new perspective included "zoning", the idea that every activity should take place in an area specially set out for the purpose to avoid interference and problems in the community. Even 
before this time there had been other theories that pointed out the complexity of urban problems. For example, Patrick Geddes (1854-1932) highlighted the importance of geography and history as differentiating elements far removed from narrow and uniform types (Geddes 1915). Within the Modernist movement, Lewis Mumford (1895-1990) had always maintained that many activities had been left out of the Athen's Charter's definition of a city, including its culture, its citizens and its social relations. In fact Mumford refused to write an introduction to Josep Lluis Sert's book (Sert 1942) precisely because Sert (1902-1983) was in favor of using the criteria of the Charter for solving the problems of modern cities.

A great deal of material has been published on this subject and our intention here is not to give a critical evaluation of this situation. However, we must at least recognize the value of the collective consideration of cities as key elements in the new culture; more than half the world's population, and almost three-quarters of Europeans now live in towns and cities. We must be aware of this in order to understand that the Taller was looking for a form of construction other than what Anna Bofill Levi described as "cold, rigid apartment blocks" (Bofill Levi 1975), repeated over and over again in the suburbs of all the cities in Europe in the form of identical, homogenized urban sprawls, and with absolutely no regard for their previous identities, their climates or histories.

In addition to these people's buildings that the Taller wanted to design, there was at the same time a desire to discover a mathematical theory of forms, or a type of obsession with creating an automatic process for generating urban landscapes from mathematical models. "Grouping" (perhaps as a compact model) appeared as a system of collective housing that could respond to the urgent need for houses (the basic right to have somewhere to live) and to systematizing the solutions. Grouping, as compared to isolation, highlights the apparent contradiction of living together but in liberty (social but independent). People wanted to live together in cities while at the same time preserving their identity and privacy, and the Theory of Forms proposed a number of different ways for them to achieve this.

\section{Modulation and Proportion}

If isometries provide a way of systematizing the process, we must also mention another element of the Theory of Forms of great importance for architecture and urban planning: the module.

Modules can be seen as the basis of a system that allows the group to be identified by using one of its parts as a measure. Basically, it involves a way of providing or describing the scale of each element, that is, showing whether it is large or small. The Japanese tatami can be considered an example of this for the way it converts a recognizable everyday object into a unit of measure, in Japanese culture, and facilitates the comprehension of an abstract concept such as proportion or size.

Both Leonardo da Vinci and Le Corbusier used the human body as the reference for measure and proportion.

In the Theory of Forms, the module is the basic element that allows the required systematization and also provides advantages for the building process. It may seem a contradiction that the method or the modulation involve structures that are 
adaptable to many different lifestyles, but we only have to look at the use of the Theory of Forms in architecture and urban planning to see that in fact no contradiction is involved.

\section{Public Spaces}

At the time when Anna Bofill belonged to the Taller, they were also interested in another important factor of urban planning considered to be a vital part of modern culture: public spaces. These are understood as something that increases in value as they change because they are responsible for catering for different types of people and activities under diverse conditions. Private individuals can make changes to their own space as they see fit (although making changes to a house may involve problems, which makes renting a flexible solution against buying as a rigid solution), but public spaces have to respond to many different needs and so cannot afford to specialize (e.g. children's playgrounds and areas for the elderly) as their basic function is to serve the needs of the entire poulation.

Jordi Borja has said that any element that carries out more than one function in a public space (and so makes it possible for people to meet and mix) is worth more than one that is aimed at one specific type of citizen (Borja 2000). The possibilities offered by the Theory of Forms therefore are not limited to private interests but are also open to public spaces. They are not only interested on what goes on behind closed doors but also in what happens outdoors. These designs have both positive and negative sides, and both are of interest.

This is where the concept of the compact city appears as an alternative to the diffuse model of the Athens Charter; it favors proximity instead of specialization and could be thought of as a mixture of the casbah (as an architectural unit) and the kibbutz (as a self-sufficient functional unit). And here the module, as a mathematical-architectural element, comes into its own as a generator of open spaces for collective activities.

Therefore, the module, the compact city, proportion, multifunctionality and social relationships can be seen as the basis that questions urban reality and joins together urban planning, architecture and mathematics.

\section{An Interview with Anna Bofill}

Below we give some of Anna Bofill's reflections on her projects in the form of extracts from an interview kindly conceded to the authors in the summer of 2016.

In those 10 years the Taller de Arquitectura was working on a number of alternatives to solve the housing problem in Spain. These alternatives were inherited from the 1933 Athens Congress and the CIAM, which proposed apartment blocks and towers for cheap housing along the lines of the model of a city in Le Corbusier's Ville Radieuse. This type of model was used for the buildings put up in the working-class districts of many cities after the Second World War. However, we rejected it out of hand at that time because it was an international solution that created the same impersonal surroundings wherever it was used and took absolutely 
no account of the lives of the residents or of the "genius loci" (a term used by Professor Christian Norberg-Schultz in the title of his book, which also had an influence on our way of thinking). This thinking is expressed synthetically in "El Manifiesto del Diablo" and was the origin of our research on large-scale social housing and the models that could be used for designing districts and even whole cities (which I call residential units and urban settlements).

In 10 years you can produce a lot of ideas, proposals, formal models, written theories and poetical writings, as well as films and musical works. I remember that the poet José Agustín Goytisolo wrote a whole book of poems entitled "Taller de Arquitectura" (published by Lumen, Barcelona, in 1977), which I recommend reading in order to better understand the essence of the ideas that we proposed, debated and agreed on as a group. Ours was by no means cold and functional work in response to commissions, but mostly projects we took on ourselves, with daily sessions of passionate debate in which we analyzed what we liked about the architecture and urban planning of the time. We would think of possible solutions and ways of tackling the problems and then share the work out according to each one's capacities and knowledge.

As for the forms themselves, which is the subject of your work, they were especially the result of the research done by Manuel Nuñez Yanowsky and me. We approached the subject from two different angles; he used intuition and trial and error, manipulation of volumes, cubes and parallelepipeds and others, while I tried to find a logical/mathematical/geometric sense to it all by finding out all that was taking place (in the 1960s and 1970s) in modular architecture and other disciplines like mathematical logic, linguistics (structuralism was then in vogue) and listening to Gabriel Ferrater explain generative grammar, interviewing Noam Chomsky in Boston, studying sociology, psychology (Skinner, among others), human geography (Henry Lefebvre, for example, and others), mathematics (Hermann Weyl, Eduard Bonet, etc.) and a long list of other topics.

And now what? The door is still open, of course. I think this information is vital and so is the use of holistics in architecture and town planning, but I have the impression that no attention is paid to these areas in Spanish schools of architecture. I always insist on this: how can we influence or transform the places we live in without detailed knowledge of the characteristics they are composed of? How can you offer people somewhere to live if you know absolutely nothing about them? I think that this is the reason for the failure of the districts that have been built in our cities since the sixties, or of the cités of Paris, to give another clear example of how the surroundings have a negative influence on the people who live there (our translation).

Acknowledgements This work has been partially supported by the Department of Applied Mathematics of Universitat Politècnica de València (PID-DMA 2014 y PID-DMA-2016).

\section{References}

Bofill Levi, Anna. 1975. Contribución al estudio de la generación de formas arquitectónicas y urbanas, Ph.D. thesis, Universitat Politècnica de Barcelona. 
Bofill Levi, Anna. 2008. Guía para el planeamiento urbanístico y la ordenación urbana con la incorporación de criterios de género. Generalitat Catalana.

Bofill Levi, Anna. 2010. Generations offorms: space to inhabit, time to think, The Schelling Lectures, Art Stock Books Ltd.

Bofill Levi, Anna, Rosa M. Dumenjó Mertí, Isabel Segura Soriano and Carmen Martinez Garrote. 1998. Las mujeres y la ciudad: libro blanco para una concepción del entorno habitado desde el punto de vista del género. Consejo de la mujer de la Comunidad de Madrid.

Borja, Jordi and Zaida Muxi. 2000. El espacio público. Ciudad y ciudadanía. Ed. Electa, Barcelona

García Hernández, Pedro. 2013. La agregación modular como mecanismo proyectual residencial en España: el Taller de Arquitectura, Ph. D. thesis. Universitat Ramón Llul. http://hdl.handle.net/ $10803 / 108286$.

Geddes, Patrick. 1915. Cities in evolution. Williams and Nortgate.

González Virós, Itziar. 2006. Anna Bofill Levi (Entrevista). Quaderns d'arquitectura i urbanisme 250: 112-19. http://www.raco.cat/index.php/QuadernsArquitecturaUrbanisme/article/view/235108/ 349829.

Martín Nieva, Helena. 2002. Número y género de dos términos: arquitectura y música, en Anna Bofill Levi. DC PAPERS: revista de crítica y teoría de la arquitectura 23 (Juliol 2012): 57-68.

Sert, Josep Lluis. 1942. Can Our Cities Survive? An ABC of Urban Problems, their Analysis, their Solutions, Cambridge, Harvard University Press.

María del Carmen Gómez-Collado I am Profesor Titular de Universidad in the Applied Mathematics Department of Universitat Politècnica de València (UPV) affiliated with the School of Architecture and a researcher of Instituto Universitario de Matemática Pura y Aplicada of UPV. My teaching work began in 1993 and it has always been linked to the university field. I received my doctorate in Mathematics in 2002 and I was awarded the Extraordinary Doctorate Award by Universidad de Valencia. My research is focused on functional analysis and I belong to national networks of Functional Analysis and Complex Analysis and Operator Theory. In 2001, I officially became a member of a research team whose projects have public subsidy from the Ministry as well as the Council of Valencia. In parallel to my research and as a result of my teaching in the School of Architecture, I have worked in different studies related to Mathematics, Architecture, and Fine Arts.

Rafael Rivera Herráez In 1975 I graduated in the School of Architecture of the Universitat Politècnica de València (UPV). I was city architect in Godella (Valencia) between 1980 and 1982, and in Valencia from 1982 and 1987. Currently, I work in my own studio (www.rsrarquitectes.com). I have developed public projects mainly schools, cultural centers, gardens, urban projects and singular projects such as the Gulliver garden in or the installation of the Dama Ibérica, both in Valencia. From 2002 I work as an associate professor in the School of Architecture of the (UPV) as a member of the Urbanism Department. I am an habitual collaborator of the Levante newspaper with opinion articles related to the city, the urbanism and the social tissue.

Macarena Trujillo Guillén From 2005 I am a professor in the Applied Mathematics department in the UPV affiliated with the School of Architecture. I am a researcher of Instituto Universitario de Matemática Pura y Aplicada of Universitat Politècnica de València. In the research sector, my area of work is focused on Biomedical Engineering (www.metablate.com). I have published 27 articles, 19 of them in JCR journals and I have two six-year research periods (2004-2009, 2010-2015). I have been researcher in 19 projects with public subside, and currently I am the main researcher coordinator of a Spanish I+D+I program (Retos de la Sociedad). In parallel to my research within Biomedical Engineering and as a result of my teaching in the School of Architecture, I have worked in different studies related to Mathematics, Architecture, and Fine arts. I have taken part in Exposición de tecnología e investigación científica en edificación (EXCO 2014) Committee 